\title{
АНАЛІЗ ПОРУШЕННЯ ВІДТВОРЕННЯ У СТАДІ МОЛОЧНОЇ ХУДОБИ
}

\section{М. С. ГОНЧАРУК}

Миколаївський національний аграрний університет(Миколаїв, Україна) zoomikola14@ukr.net

Аналіз відтворення у стаді української чорно-рябої молочної породи показав, що залежно від числа лактацій кількість тільних корів коливалась у межах 24,1-29,5\%, умовно здорових - 32,2-34,9\%, не тільних - 2,4-7,2\%, із гінекологічними хворобами -34,4-36,8\%. Не виявлено залежності частоти порушення відтворення від віку першого осіменіння телиць $і$ величини середньодобового надою корів. Корови, у яких не зафіксовано порушення відтворення, мали у середньому на 10 кг $(P<0,05)$ вищу живу масу за першого осіменіння. Зі збільшенням живої маси за першого осіменіння із 350 кг і нижче до 441 кг і вище частота порушення відтворення знижується із 50\% до 35\%. Виявлено залежність порушення відтворення від оцінки екстер'єрного типу корів: зростання оцінки екстер'єрного типу із 65-74 до 90 балів $i$ вище зумовлює зниження порушення відтворення із 54\% до 31\%.

Сила впливу віку $і$ живої маси за першого осіменіння телиць на частоту порушення відтворення становила 5,0\% і 24,9\%, відповідно, номера лактації-18,2\%, оиінки екстер'єрного типу - 14,0\%, середньодобового надою - 14,5\%, однак у всіх випадках цей вплив був недостовірним $(P>0,05)$.

Ключові слова: молочна худоба, відтворення, порушення відтворення, вік і жива маса за першого осіменіння, лінійна оцінка, середньодобовий надій, сила впливу

\section{ANALYSIS OF REPRODUCTIVE DISORDERS IN THE DAIRY HERD}

\section{S. Goncharuk}

Mykolaiv National Agrarian University (Mykolaiv, Ukraine)

The analysis of reproduction in the herd of Ukrainian black and white milk breed showed that, depending on the number of lactation, the number of pregnant cows was varies within 24,1-29,5\%, conditionally healthy $-32,2-34,9 \%$, not pregnant - 2,4-7,2\%, with gynecological diseases - 34,4$36,8 \%$. No dependence of the frequency of reproductive disorders from the age at first mating of the heifers and the average daily milk yield of cows was found. Cows without reproductive disorders had an average live weight $10 \mathrm{~kg}$ above $(P<0,05)$ at the first mating. With the increasing of body weight at first mating from $350 \mathrm{~kg}$ and below to $441 \mathrm{~kg}$ or more, the reproductive disorders decreases from $50 \%$ to 35\%. The dependence of the reproductive disorders on the exterior type evaluation of cows was found: an increasing of exterior type evaluation from 65-74 to 90 points and above results in a decrease in reproductive disorders from $54 \%$ to $31 \%$.

The influence of age and body weight at first mating of heifers on the frequency of reproductive disorders was $5,0 \%$ and $24,9 \%$, respectively, lactation number - 18,2\%, exterior type evaluation$14,0 \%$, average daily milk yield -14,5\%, however, in all cases this effect was unreliable $(P>0,05)$. Keywords: dairy cattle, reproduction, reproductive disorders, age and body weight at first mating, linear evaluation, average daily milk yield, influence 
АНАЛИЗ НАРУШЕНИЯ ВОСПРОИЗВОДСТВА В СТАДЕ МОЛОЧНОГО СКОТА Н. С. Гончарук

Николаевский национальный аграрный университет (Николаев, Украина)

Анализ воспроизводства в стаде украинской черно-пестрой молочной породы показал, что в зависимости от числа лактаций количество стельных коров колебалось в пределах 24,1-29,5\%, условно здоровых - 32,2-34,9\%, не стельных - 2, 4-7,2\%, с гинекологическими болезнями - 34,4-36,8\%. Не выявлена зависимость частоты нарушения воспроизводства от возраста первого осеменения телок и величины среднесуточного удоя коров. Коровы, у которых зафиксированы нарушения воспроизводства, имели в среднем на 10 кг (P<0,05)более высокую живую массу при первом осеменении. С увеличением живой массы при первом осеменения с 350 кг и ниже до 441 кг и выше частота нарушения воспроизводства снижается с 50\% до 35\%. Выявлена зависимость нарушения воспроизводства от оценки экстерьерного типа коров: увеличение оченки экстерьерного типа с 65-74 до 90 баллов и выше приводит к снижению нарушения воспроизводства с 54\% до 31\%.

Сила влияния возраста и живой массы при первом осеменении телок на частоту нарушения воспроизводства составляла 5,0\% и 24,9\%, соответственно, номера лактации 18,2\%, оценки экстерьерного типа - 14,0\%, среднесуточного удоя - 14,5\%, однако во всех случаях это влияние было недостоверным $(P>0,05)$.

Ключевые слова: молочный скот, воспроизводство, нарушение воспроизводства, возраст и живая масса при первом осеменении, линейная оценка, среднесуточный удой, сила влияния

Вступ. Основними чинниками, які визначають ефективність молочного скотарства є високий рівень молочної продуктивності та регулярне відтворення поголів'я [1]. Взаємопов'язаність молочної продуктивності і відтворювальної здатності молочної худоби доведена численними дослідженнями. Зокрема М. I. Кузів і С. І. Федорович [2] зазначають, що частка впливу тривалості сервіс-періоду на молочну продуктивність корів коливалась у межах 7,029,7\%, міжотельного періоду - 8,8-31,8\%залежно від господарства, лактації і показника. Р. В. Ставецька та О. В. Бойко [3] повідомляють про силу впливу сервіс-періоду на показники молочної продуктивності, господарського і довічного використання на рівні 6,2-49,5\%.

Несприятливі умови середовища посилюють антагонізм між молочною продуктивністю і відтворювальною здатністю. Згідно результатів досліджень J. F. Kearney et al [4], величина від'ємних генетичних кореляцій між надоєм і кількістю соматичних клітин та надоєм і запліднюваністю корів достовірно вища за гірших умов середовища порівняно із оптимальними умовами. Раніше оптимальною тривалістю сервіс-періоду вважали 80-90 днів, нині повідомляється про оптимальну тривалість сервіс-періоду на рівні 90-120 днів [5, 6], однак у високопродуктивних стадах його тривалість досить часто є вищою [7]. Наприклад, у стаді української чорно-рябої молочної породи ТОВ «Агро-Старт» Черкаської області вища довічна продуктивність спостерігалась у корів із тривалістю сервіс-періоду 91-180 днів, від яких за життя у середньому отримано 3,73 телят, довічний надій - 19185 кг, молочного жиру + молочного білка - 1371 кг, надій на один день життя - 7,16 кг. Вищий надій у розрахунку на один день лактації відмічено у корів із тривалістю сервіс-періоду $121-150$ днів $(13,8$ кг, Р <0,01) та 211 днів і більше $(13,9$ кг, $\mathrm{P}<0,05)$ [3].

Часто у високопродуктивних стадах спостерігається погіршення стану відтворення: подовжується тривалість сервіс- і міжотельного періодів, зростає індекс осіменіння, знижується вихід телят на 100 корів, тварин вибраковують зі стада впродовж першої-другої лактацій через порушення відтворення і гінекологічні хвороби $[8,9]$. Причинами цього називають спрямовану однобічну селекцію на зростання надою, ембріональну смертність, незадовільну роботу техніка штучного осіменіння, високу скупченість тварин, їх захворюваність, а також належність до певної породи (у першу чергу, голштинської), породність тварин (повідомляється про 
погіршення стану відтворення у стадах із високою умовною кровністю за голштинською породою), використання інбридингу та ін. [10, 11, 12].

Професор Х. Больвайн із Вищої ветеринарної школи Ганновера називає основними причинами погіршення стану відтворення у високопродуктивних стадах худоби негативний енергетичний баланс та низький рівень гормонів у високопродуктивних корів, які потрібні для запліднення і нормального перебігу тільності, а також різноманітні запальні процеси в організмі корів. Він не рекомендує осіменяти високопродуктивних корів у першу охоту після отелення, оскільки слизова оболонка матки ще повністю не відновлена і не готова до прийняття плоду, тому спостерігається значно нижчий відсоток тільності [13].

J. M. Schefers et al [14] виділив 41 чинник, які на 35-40\% визначають відтворювальну здатність молочних корів, основними із яких є відсоток повторних осіменінь через 4-17 днів після штучного осіменіння, скупченість корів у приміщеннях, тривалість періоду, необхідного для інволюції репродуктивної системи, кількість соматичних клітин у молоці, навантаження на техніка штучного осіменіння, синхронізація охоти, використання душу для охолодження у спекотний період та ін.

Незважаючи на те, що ознаки відтворювальної здатності є низькоуспадковуваними і досягти їх селекційного поліпшення досить складно, вони включені до комплексних селекційних індексів, зокрема американських індексів TPI і LNM\$ [15], що свідчить про можливості селекційного поліпшення показників відтворювальної здатності молочної худоби, а, отже, і стану відтворення у сучасних високопродуктивних стадах.

Метою дослідження був аналіз стану відтворення у стаді української чорно-рябої молочної породи та виявлення частоти порушення відтворення залежно від віку і живої маси телиць за першого осіменіння, числа лактацій, лінійної оцінки екстер'єрного типу корів та їх середньодобового надою.

Матеріали та методи досліджень. До аналізу включено 569 корів ТОВ «АФ Матюші» Київської області, із них першої лактації 195 голів, другої - 166 голів, третьої лактації і старше - 208 голів. Для проведення аналізу корови були розділені на дві групи: 1) без порушення відтворення (тільні та умовно здорові); 2) із порушенням відтворення (не тільні та із гінекологічними захворюваннями). Тільність корів підтверджувалась УЗД дослідженням, до умовно здорових були віднесені тварини до 83 днів після отелення і після першого і другого осіменінь до проведення УЗД діагностики, не тільні - корови після двох і більше підтверджених неплідних осіменінь.

Оцінку екстер'єрного типу корів проведено у віці 2-4 місяців після першого отелення за методикою лінійної класифікації [16]. Середньодобовий надій корів проаналізовано за другий місяць лактації. Силу впливу досліджених чинників обчислено одно факторним дисперсійним аналізом [17]. Обчислення проведено методами математичної статистики програмного пакету «Statistica-10».

Результати досліджень. У 2017 році середній надій за 305 днів у стаді української чорно-рябої молочної породи ТОВ «АФ Матюші» становив 6583 кг за вмісту жиру 3,68\% і 242 кг молочного жиру та 3,07\% і 202 кг молочного білка. Середня тривалість сервіс-періоду - 178 днів, між отельного періоду - 458 днів, індекс осіменіння - 3,30, коефіцієнт відтворювальної здатності - 0,80. Тобто це стадо характеризується досить високою молочною продуктивністю та зниженими показниками відтворення, зокрема тривалість сервіс-періоду майже вдвічі вища за оптимальне значення.

Залежно від числа лактацій кількість тільних корів у стаді коливалась у межах 24,1$29,5 \%$, умовно здорових - 32,2-34,9\%, не тільних $-2,4-7,2 \%$, із гінекологічними хворобами 34,4-36,8\% (рис. 1). Найбільш поширеними гінекологічними хворобами були метрит, гіпофункція і кистоз яєчників, абсцес матки. На думку С. А. Власенко [18] різноманітні проблеми зі здоров'ям, порушення фертильності та навіть повна втрата репродуктивної функції у високопродуктивних корів пов'язані з їх високою молочною продуктивністю, що супроводжується суттєвим збільшенням концентрації пролактину в крові. За рахунок його гальмівного ефекту 
щодо фолікулогенезу спостерігається порушення статевої циклічності у високопродуктивних корів.

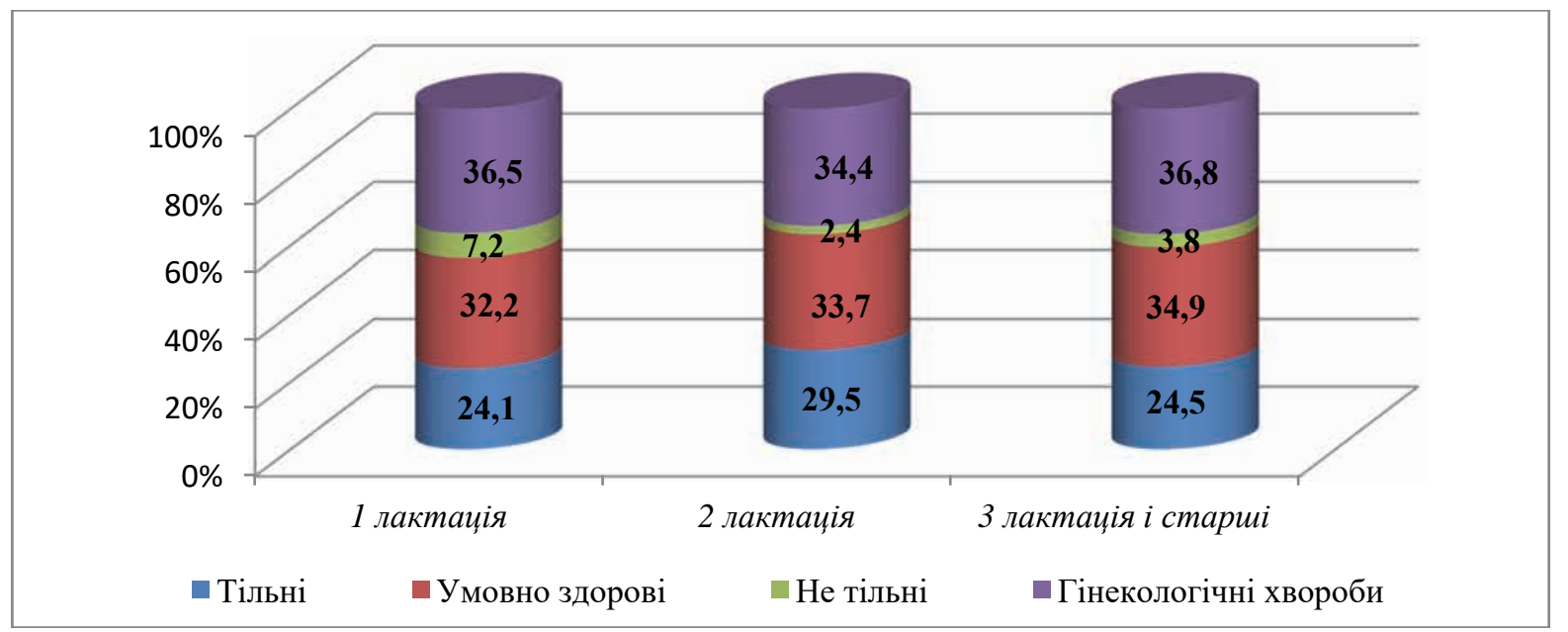

Рис. 1 Характеристика відтворення у стаді залежно від номера лактації

Примітка: * Корови до 83 днів після отелення і після першого і другого осіменінь до проведення УЗД діагностики.

Відомо, що інтенсивне вирощування ремонтних телиць та їх своєчасного осіменіння дає змогу вводити у стадо нетелей з високим потенціалом за молочною продуктивністю і відтворювальною здатністю. Оптимальним віком осіменіння телиць вважається 16-18 місяців за живої маси 70-75\% маси дорослої корови. У дослідженому стаді вік першого осіменіння телиць $\epsilon$ дещо вищим за оптимальне значення - у середньому 19,6 місяців (табл. 1).

1. Характеристика відтворення у стаді залежно від віку першого осіменіння телиць

\begin{tabular}{|c|c|c|c|c|c|c|}
\hline \multirow{3}{*}{$\begin{array}{c}\text { Вік першого } \\
\text { осіменіння, місяців }\end{array}$} & \multicolumn{3}{|c|}{ Без порушення відтворення } & \multicolumn{3}{|c|}{ Із порушенням відтворення } \\
\hline & \multicolumn{2}{|c|}{ корів } & \multirow{2}{*}{$\begin{array}{c}\text { вік першого } \\
\text { осіменіння, місяців } \\
\text { (у середньому) }\end{array}$} & \multicolumn{2}{|c|}{ корів } & \multirow{2}{*}{$\begin{array}{c}\text { вік першого } \\
\text { осіменіння, місяців } \\
\text { (у середньому) }\end{array}$} \\
\hline & голів & $\%$ & & голів & $\%$ & \\
\hline до 16,0 & 71 & 55 & \multirow{5}{*}{$19,7 \pm 0,28$} & 58 & 45 & \multirow{5}{*}{$19,5 \pm 0,38$} \\
\hline $16,1-18,0$ & 90 & 62 & & 54 & 38 & \\
\hline $18,1-20,0$ & 68 & 61 & & 43 & 39 & \\
\hline $20,1-22,0$ & 31 & 52 & & 29 & 48 & \\
\hline 22,1 і вище & 79 & 63 & & 46 & 37 & \\
\hline
\end{tabular}

Певних тенденцій щодо зміни частоти порушення відтворення залежно від віку першого осіменіння не виявлено. Залежно від віку першого осіменіння частка корів без порушення відтворення варіювала від 52 до 63 \%, із порушенням відтворення - від 37 до 48 \%.

У середньому жива маса телиць за першого осіменіння становила 385 кг (табл. 2).

2. Характеристика відтворення у стаді залежно від жсиоӥ маси телиць за першого осіменіння

\begin{tabular}{|c|c|c|c|c|c|c|}
\hline \multirow{3}{*}{$\begin{array}{c}\text { Жива маса за першого } \\
\text { осіменіння, кг }\end{array}$} & \multicolumn{3}{|c|}{ Без порушення відтворення } & \multicolumn{3}{|c|}{ Із порушенням відтворення } \\
\hline & \multicolumn{2}{|c|}{ корів } & \multirow{2}{*}{$\begin{array}{c}\text { жива маса за першого } \\
\text { осіменіння, кг } \\
\text { (у середньому) }\end{array}$} & \multicolumn{2}{|c|}{ корів } & \multirow{2}{*}{$\begin{array}{c}\text { жива маса за першого } \\
\text { осіменіння, кг } \\
\text { (у середньому) }\end{array}$} \\
\hline & голів & $\%$ & & голів & $\%$ & \\
\hline до 350 & 68 & 50 & \multirow{5}{*}{$390 \pm 2,5^{*}$} & 67 & 50 & \multirow{5}{*}{$380 \pm 3,3$} \\
\hline $351-380$ & 81 & 56 & & 63 & 44 & \\
\hline $381-410$ & 84 & 62 & & 51 & 38 & \\
\hline $411-440$ & 48 & 60 & & 32 & 40 & \\
\hline 441 і вище & 49 & 65 & & 26 & 35 & \\
\hline
\end{tabular}

Примімка: ${ }^{*} P<0,05$. 
Проведений аналіз показав, що корови, у яких не зафіксовано порушення відтворення впродовж 2017 року, мали у середньому достовірно вищу живу масу за першого осіменіння на 10 кг (Р < 0,05). Зі зростанням живої маси за першого осіменіння із 350 кг і нижче до 441 кг і вище кількість корів із порушенням відтворення зменшується із 50\% до $35 \%$.

Важливою складовою селекції молочної худоби є лінійна оцінка корів за екстер'єрним типом, оскільки екстер'єр є зовнішнім проявом конституції тварин, їх індивідуальних особливостей, породної типовості, за екстер'єром можна судити про напрям продуктивності тварин, стан їх здоров'я, відтворювальну здатність та прогнозувати тривалість продуктивного використання у стаді. У ТОВ «АФ Матюші» більшість тварин отримали досить високу оцінку за екстер'єрним типом. Переважній частці корів за екстер'єр присвоєно класи «дуже добре» (45\% корів від загального поголів’я) та «добре з плюсом» (30\%) (табл. 3).

3. Характеристика відтворення у стаді залежно від оцінки екстер'срного типу корів

\begin{tabular}{|c|c|c|c|c|c|c|c|}
\hline \multirow{3}{*}{$\begin{array}{c}\text { Загальна оцінка, } \\
\text { балів }\end{array}$} & \multirow{3}{*}{ Клас* } & \multicolumn{3}{|c|}{ Без порушення відтворення } & \multicolumn{3}{|c|}{ Із порушенням відтворення } \\
\hline & & \multicolumn{2}{|c|}{ корів } & \multirow{2}{*}{$\begin{array}{c}\text { загальна оцінка, } \\
\text { балів (у середньому) }\end{array}$} & \multicolumn{2}{|c|}{ корів } & \multirow{2}{*}{$\begin{array}{c}\text { загальна оцінка, балів } \\
\text { (у середньому) }\end{array}$} \\
\hline & & голів & $\%$ & & голів & $\%$ & \\
\hline 90 і вище & $\mathrm{B}$ & 47 & 69 & \multirow{5}{*}{$85,0 \pm 0,24 * *$} & 21 & 31 & \multirow{5}{*}{$83,9 \pm 0,32$} \\
\hline $85-89$ & ДД & 154 & 60 & & 104 & 40 & \\
\hline $80-84$ & ДП & 97 & 56 & & 76 & 44 & \\
\hline $75-79$ & Д & 22 & 48 & & 24 & 52 & \\
\hline $65-74$ & 3 & 11 & 46 & & 13 & 54 & \\
\hline
\end{tabular}

Примімка: ${ }^{*}$ В - відмінно; ДД- дуже добре; ДП - добре з плюсом; Д- добре; 3 - задовільно; ** $P<0,01$.

Корови із вищою оцінкою екстер'єрного типу характеризувались нижчою частотою порушення відтворення. У групі корів без порушення відтворення у середньому загальна оцінка екстер'єрного типу корів була вищою на 1,1 бал $(\mathrm{P}<0,01)$ порівняно із тваринами із порушенням відтворення. Зі зростанням оцінки екстер'єрного типу із 65-74 до 90 балів і вище поголів'я корів із порушенням відтворення зменшується із 54\% до $31 \%$.

У результаті проведеного аналізу встановлено, що у групі корів із порушенням відтворення на другому місяці лактації був достовірно вищий середньодобовий надій - на 1,6 кг $(\mathrm{P}<0,05)$ порівняно із тваринами без порушення відтворення (табл. 4), тобто у корів із вищою молочною продуктивністю частіше спостерігаються порушення відтворення.

4. Характеристика відтворення у стаді залежно від величини середньодобового надою

\begin{tabular}{|c|c|c|c|c|c|c|}
\hline \multirow{3}{*}{$\begin{array}{c}\text { Середньодобовий } \\
\text { надій, кг }\end{array}$} & \multicolumn{3}{|c|}{ Без порушення відтворення } & \multicolumn{3}{|c|}{ Із порушенням відтворення } \\
\hline & \multicolumn{2}{|c|}{ корів } & \multirow{2}{*}{$\begin{array}{c}\text { середньодобовий надій } \\
\text { (у середньому) }\end{array}$} & \multicolumn{2}{|c|}{ корів } & \multirow{2}{*}{$\begin{array}{c}\text { середньодобовий надій } \\
\text { (у середньому) }\end{array}$} \\
\hline & голів & $\%$ & & голів & $\%$ & \\
\hline 20,0 кг і менше & 47 & 57 & \multirow{5}{*}{$26,2 \pm 0,40$} & 36 & 43 & \multirow{5}{*}{$27,8 \pm 0,49^{*}$} \\
\hline $20,1-25,0$ & 98 & 62 & & 60 & 38 & \\
\hline $25,1-30,0$ & 83 & 52 & & 78 & 48 & \\
\hline $30,1-35,0$ & 50 & 63 & & 29 & 37 & \\
\hline 35,1 і вище & 47 & 53 & & 41 & 47 & \\
\hline
\end{tabular}
$P<0,05$.

Примітка: * Частота порушення відтворення у стаді корів по добовому надою за другий місяць лактації,

Однак певних тенденцій зміни середньодобового надою у досліджених групах корів виявлено не було. Залежно від величини середньодобового надою у групі без порушення відтворення частка корів становила 52-63\%, із порушенням відтворення - 37-48\%.

Одно факторним дисперсійним аналізом встановлено, що сила впливу досліджуваних ознак на частоту порушення відтворення у стаді варіювала від 5,0 до 24,9\%, однак у всіх випадках вона була недостовірною (Р > 0,05) (табл. 5).

Сила впливу віку першого осіменіння телиць на стан відтворення у стаді та частоту його порушення на була на рівні 5,0\%, живої маси за першого осіменіння - 24,9\%, номера лактації $18,2 \%$, оцінки екстер'єрного типу - $14,0 \%$, середньодобового надою - 14,5\%. Недостовірність 
впливу досліджених чинників на стан відтворення у стаді свідчить про суттєву роль середовищних чинників у формуванні відтворювальної здатності корів.

5. Сила впливу досліджуваних ознак на частоту порушення відтворення у стаді

\begin{tabular}{|c|l|c|c|c|}
\hline \multirow{2}{*}{$№$ 3/п } & \multicolumn{3}{|c|}{ Ознака } & \multicolumn{3}{|c|}{ Показник } \\
\cline { 3 - 5 } & \multicolumn{1}{|c|}{$\eta_{\mathrm{x}, \%}$} & $\mathrm{~F}$ & $\mathrm{P}$ \\
\hline 1 & Вік першого осіменіння, місяців & 5,0 & 0,90 & $>0,05$ \\
\hline 2 & Жива маса за першого осіменіння, місяців & 24,9 & 2,65 & $>0,05$ \\
\hline 3 & Номер лактації & 18,2 & 1,33 & $>0,05$ \\
\hline 4 & Оцінка екстер’єрного типу & 14,0 & 2,33 & $>0,05$ \\
\hline 5 & Середньодобовий надій, кг & 14,5 & 1,35 & $>0,05$ \\
\hline
\end{tabular}

Висновки. Встановлено, що залежно від числа лактацій кількість тільних корів у стаді ТОВ «АФ Матюші» коливалась у межах 24,1-29,5\%, умовно здорових - 32,2-34,9\%, не тільних $-2,47,2 \%$, із гінекологічними хворобами - 34,4-36,8\%. Певних тенденцій щодо зміни частоти порушення відтворення залежно від віку першого осіменіння телиць і величини середньодобового надою не виявлено. Однак виявлені певні відмінності за частотою порушення відтворення залежно від живої маси телиць за першого осіменіння і оцінки екстер'єрного типу. Зокрема, за зростанням живої маси за першого осіменіння із 350 кг і менше до 441 кг і вище кількість корів із порушенням відтворення зменшується із 50\% до 35\%, аза зростанням оцінки екстер'єрного типу із 65-74 до 90 балів і вище поголів'я корів із порушенням відтворення зменшується із 54\% до $31 \%$.

Найбільш сильний вплив на частоту порушення відтворення у стаді мала жива маса телиць за першого осіменіння $\left(\eta^{2} x=24,9 \%\right)$, найслабший - вік першого осіменіння телиць $\left(\eta^{2}=5,0 \%\right)$.

\section{БІБЛІОГРАФІЯ}

1. LeBlanc, S. Economics of improving reproductive performance in dairy herds / S. LeBlanc // Advanced Dairy Technology. - 2007. - Vol. 19. - P. 201-214.

2. Кузів, М. І. Відтворювальна здатність корів української чорно-рябої молочної породи / М. І. Кузів, Є. І. Федорович // Науковий вісник ЛНУВМБТ імені С. 3. Гжицького. - Львів, 2016. - Т. 18, № 2 (67). - С. 120-123.

3. Ставецька, Р. В. Вплив тривалості сервіс-періоду на показники молочної продуктивності та господарського використання молочних корів / Р. В. Ставецька, О. В. Бойко // Технологія виробництва і переробки продукції тваринництва : зб. наук. праць. - Біла Церква, 2015. № 2 (120). - С. 205-210.

4. Kearney, J. F. Genotype $\times$ environment interaction for grazing vs confinement II. Health and reproduction traits / J. F. Kearney, M. M. Schutz, P. J. Boettcher // J. Dairy sci. - 2004. - Vol. 87. P. 510-516.

5. Ставецька, Р. В. Вплив тривалості сервіс-періоду на продуктивні та інші показники відтворної здатності корів / Р. В. Ставецька // Збірник наукових праць ВНАУ. Серія «Сільськогосподарські науки». - Вінниця, 2012. - Вип. 4 (62). - С. 106-111.

6. Юмагузин, И. Воспроизводство стада - важный элемент эффективности молочного скотоводства / И. Юмагузин, Ф. Яхин, С. Ардаширов // Аграрное решение. - 2011. - № 3. C. $40-41$.

7. Зотько, М. О. Відтворення великої рогатої худоби у Вінницькій області / М. О. Зотько, Н. В. Гуцол, Л. В. Вишневський // Збірник наукових праць ВНАУ. Серія «Сільськогосподарські науки». - Вінниця, 2011. - Вип. 8 (48). - С. 16-19.

8. Selection for female fertility using censored fertility traits and investigation of the relationship with milk production / O. Gonzalez-Recio, R. Alenda, Y. M. Chang, K. A. Weigel, D. Gianola // J. Dairy sci. - 2006. - Vol. 89. - P. 4438-4444. 
9. Barth, A. D. The effect of nutrition on sexual development of bulls / A. D. Barth, L. F. C. Brito, J. P. Kastelic // Theriogenology. - 2008. - Vol. 70, Issue 3. - P. 485-494.

10. Козирь, В. Підвищення надоїв може погіршити відтворення / В. Козирь, Т. Мовчан // Тваринництво України. - 2010. - № 10. - С. 16-19.

11. Підпала, Т. Відтворення великої рогатої худоби за безприв'язного утримання / Т. Підпала, О. Цхвітава, С. Ясєвін // Тваринництво України. - 2011. - № 7. - С. 10-12.

12. Hudson, C. D. Associations between udder health and reproductive performance in United Kingdom dairy cows / C. D. Hudson, A. J. Bradley, J. E. Breen, M. J. Green // J. Dairy sci. - 2012. Vol. 95. - № 7. - P. 3683-3697.

13. Больвайн, Х. Снижающаяся плодовитость - проблема высокопродуктивного скота / Х. Больвайн // Perfect Agriculture. - Январь 2011. - С. 31-33.

14. Management practices associated with conception rate and service rate of lactating Holstein cows in large, commercial dairy herds / J. M. Schefers, K. A. Weigel, C. L. Rawson, N. R. Zwald, N. B. Cook // J. Dairy sci. - 2010. - Vol. 93, Issue 4. - P. 1459-1467.

15. Stillbirth (co)variance components for a sire-maternal grandsire threshold model and development of a calving ability index for sire selection / J. B. Cole, G. R. Wiggans, P. M. VanRaden, R. H. Miller // J. Dairy sci. - 2007. - Vol. 90, Issue 5. - P. 2489-2496.

16. Методика лінійної класифікації корів молочних і молочно-м'ясних порід за типом / Л. М. Хмельничий, В. І. Ладика, Ю. П. Полупан, А. М. Салогуб. - Суми : «Мрія-1», 2008. $28 \mathrm{c}$.

17. Плохинский, Н. А. Биометрия / Н. А. Плохинский. - М. : Изд-во МГУ, 1970. - 367 с.

18. Власенко, С. А. Висока продуктивність корів як сприяючий фактор для зниження відтворної здатності та розвитку післяродових акушерських хвороб і гнійно-некротичних уражень в ділянці пальців / С. А. Власенко // Науковий вісник ветеринарної медицини : зб. наук. праць. - Біла Церква, 2013. - Вип. 11 (101). - С. 37-43.

\section{REFERENCES}

1. LeBlanc, S. 2007. Economics of improving reproductive performance in dairy herds. Advanced Dairy Technology. 19:201-214 (in English).

2. Kuziv, M. I. and Ye. I. Fedorovych. 2016. Vidtvoriuvalna zdatnist koriv ukrainskoi chorno-riaboi molochnoi porody - Reproductive ability of cows of Ukrainian black and white dairy breed. Naukovyi visnyk Lvivskoho natsionalnoho universytetu veterynarnoi medytsyny ta biotekhnolohii imeni S. Z. Hzhytskoho - Scientific bulletin of Lviv National University of Veterinary Medicine and Biotechnologies named after S. Z. Gzhytskyi. 18.2(67):120-123 (in Ukrainian).

3. Stavetska, R. V. and O. V. Boiko. 2015. Vplyv tryvalosti servis-periodu na pokaznyky molochnoi produktyvnosti ta hospodarskoho vykorystannia molochnykh koriv - Effect of the service period on milk productivity indicators and usage of dairy cows. Tekhnolohiia vyrobnytstva $i$ pererobky produktsii tvarynnytstva: zbirnyk naukovyh prats - Animal produce and processing technologies: collection of scientific works. Bila Tserkva. 2(120):205-210 (in Ukrainian).

4. Kearney, J. F, M. M. Schutz, and P. J. Boettcher. 2004. Genotype $\times$ environment interaction for grazing vs confinement II. Health and reproduction traits. J. Dairy sci. 87:510-516 (in English).

5. Stavetska, R. V. 2012. Vplyv tryvalosti servis-periodu na produktyvni ta inshi pokaznyky vidtvornoi zdatnosti koriv - Effect of the service period on productive performance and other reproductive ability of cows. Zbirnyk naukovykh prats Vinnytskoho natsionalnoho ahrarnoho universytetu, seriia «Silskohospodarski nauky» - Collection of scientific works of of Vinnytsia National Agrarian University, series "Agricultural Sciences". Vinnitsa. 4(62):106-111 (in Ukrainian).

6. Yumahuzyn, Y., F. Yakhyn and S. Ardashyrov. 2011. Vosproizvodstvo stada - vazhnyiy element effektivnosti molochnogo skotovodstva - Reproduction of the herd is an important element of the efficiency of dairy cattle breeding. Ahrarnoe reshenye - Agrarian solution. 3:40-41 (in Russian). 
7. Zotko, M. O., N. V. Hutsol and L. V. Vyshnevskyi. 2011. Vidtvorennia velykoi rohatoi khudoby u Vinnytskii oblasti - Reproduction of cattle in Vinnytsia region. Zbirnyk naukovykh prats Vinnytskoho natsionalnoho ahrarnoho universytetu, seriia «Silskohospodarski nauky» - Collection of scientific works of Vinnytsia National Agrarian University, series "Agricultural Sciences". Vinnitsa. 8(48):16-19 (in Ukrainian).

8. Gonzalez-Recio, O., R. Alenda, Y. M. Chang, K. A. Weigel, and D. Gianola. 2006. Selection for female fertility using censored fertility traits and investigation of the relationship with milk production. J. Dairy Sci. 89:4438-4444 (in English).

9. Barth, A. D., L. F. C. Brito, and J. P. Kastelic. 2008. The effect of nutrition on sexual development of bulls. Theriogenology. 70(3):485-494 (in English).

10. Kozyr, V. and T. Movchan. 2010. Pidvyshchennia nadoiv mozhe pohirshyty vidtvorennia Increasing of milk yield can worsen the reproduction. Tvarynnytstvo Ukrainy - Livestock of Ukraine. 10:16-19 (in Ukrainian).

11. Pidpala, T., O. Tskhvitava, and S. Yasievin. 2011. Vidtvorennia velykoi rohatoi khudoby za bezpryviaznoho utrymannia - Reproduction of cattle in loose housing systems. Tvarynnytstvo Ukrainy - Livestock of Ukraine. 7:10-12 (in Ukrainian).

12. Hudson, C. D., A. J. Bradley, J. E. Breen, and M. J. Green. 2012. Associations between udder health and reproductive performance in United Kingdom dairy cows. J. Dairy Sci. 95 (7):3683-3697 (in English).

13. Bolvayn, H. 2011. Snizhayuschayasya plodovitost - problema vyisokoproduktivnogo skota Decreased fertility - the problem of highly productive livestock. Perfect Agriculture. January: 31-33 (in Russian).

14. Schefers, J. M., K. A. Weigel, C. L. Rawson, N. R. Zwald, and N. B. Cook. 2010. Management practices associated with conception rate and service rate of lactating Holstein cows in large, commercial dairy herds. J. Dairy Sci. 93 (4):1459-1467 (in English).

15. Cole, J. B., G. R. Wiggans, P. M. VanRaden, and R. H. Miller. 2007. Stillbirth (co)variance components for a sire-maternal grandsire threshold model and development of a calving ability index for sire selection. J. Dairy Sci. 90(5):2489-2496 (in English).

16. Khmelnychyi, L. M., V. I. Ladyka, Yu. P. Polupan, and A. M. Salohub. 2008. Metodyka liniinoi klasyfikatsii koriv molochnykh i molochno-miasnykh porid za typom - Method of linear classification of cows of dairy and dairy-meat breeds by type. Sumy, «Mriia-1», 28 (in Ukrainian).

17. Plohinskiy, N. A. 1970. Biometriya - Biometry. Moskva, Izdatelstvo MGU, 367 (in Russian).

18. Vlasenko, S. A. 2013. Vysoka produktyvnist koriv yak spryiaiuchyi faktor dlia znyzhennia vidtvornoi zdatnosti ta rozvytku pisliarodovykh akusherskykh khvorob i hniino-nekrotychnykh urazhen $\mathrm{v}$ diliantsi paltsiv - High productivity of cows as a contributing factor for reducing reproductive ability and development of postnatal obstetric diseases and purulent necrotic lesions in the area of fingers. Naukovyi visnyk veterynarnoi medytsyny: zbirnyk naukovyh prats - Scientific Herald of Veterinary Medicine: Collection of scientific works. Bila Tserkva. 11(101):37-43 (in Ukrainian). 